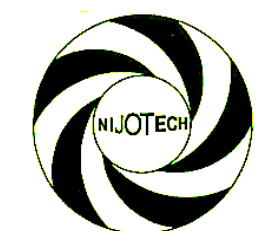

Nigerian Journal of Technology (NIJOTECH)

Vol. 39, No. 2, April 2020, pp. 621 - 631

Copyright@ Faculty of Engineering, University of Nigeria, Nsukka,

Print ISSN: 0331-8443, Electronic ISSN: 2467-8821

www.nijotech.com

http://dx.doi.org/10.4314/njt.v39i2.34

\title{
GROUNDWATER DEPLETION IN THE UPPER AQUIFER OF THE CHAD FORMATION, CHAD BASIN, NORTH-EASTERN NIGERIA
}

\author{
S. Adamu ${ }^{1}$, H. M. Sadiq ${ }^{2} *$, M. G. Kodomi ${ }^{3}$ and I. B. Wulo ${ }^{4}$ \\ $\mathbf{1 , 2 , 3 , 4}$, DePARTMENT OF GEOLOGY, UNIVERSITY OF MAIDUGURI, MAIDUGURI, BORNO STATE, NIGERIA \\ E-mail addresses: 1 drsani.gwoza@gmail.com, 2 anjusadiq@yahoo.com, \\ 3 mustaphakodomi@gmail.com, 4 ibukarwulo@yahoo.com
}

\begin{abstract}
This paper examines the present groundwater level changes in the Upper aquifer of Chad Formation in Borno basin measured in the year 2007, 2008, 2009, 2011 and 2012. The study involved collection of topographic maps of scale 1:500,000 on Nigerian sheet 4 covering the study area. Previous published literatures on the basin were also collected. Hand dug wells and their elevation were located and measured with satellite navigator. Findings from the results shows that, the Upper aquifer is a phreatic aquifer separated by thin clay layer into " $A$ " sub-zone with depth ranging from 1 to $10 \mathrm{~m}$, "B" sub-zone with depth ranging from 10 to $60 \mathrm{~m}$ and " $C$ " sub-zone with depth ranging from 60 to $100 \mathrm{~m}$. From the study, it can be deduced that, the $C$ sub-zone is not recharging from seasonal infiltration of meteoric water or from the horizontal stream flow, it rather shows a depleting groundwater level. It was proved that rain of wet seasons do not recharge Upper $C$ subzone to the previous wet season level, and thus the water table in the Upper $C$ zones will be exhausted if the aquifer is not recharged at the present level of abstraction.
\end{abstract}

Keywords: Groundwater, Chad Basin, Phreatic aquifer, Depletion level and Upper aquifer.

\section{INTRODUCTION}

Chad Basin is the largest inland drainage basin in Africa located within latitudes $11^{0} 25^{1} \mathrm{~N}$ to $13^{0} 30^{1} \mathrm{~N}$ and longitudes $11^{0} 35^{1} \mathrm{E}$ to $14^{0} 00^{1} \mathrm{E}$. The climate is semi arid dry tropics with low rainfall and high temperature a fertile area with great agricultural potential (Figure 2). This potential is limited by scarcity of water. Surface water in streams appear seasonally for couple of months, usually from August to October while for the rest of the year streams are dry and the only source of water is groundwater.

\subsection{Background}

The principal sources of water supply in the Borno Basin are surface ponds, rivers and groundwater, this surface water has disappeared and groundwater in hand dugs wells and boreholes in villages and urban settlement are drying up in the study area located within Borno Basin (Figure 2).

The groundwater levels are found in Chad Formation in the Upper, Middle and Lower aquifer [1].
Groundwater levels every year becomes deeper and water is becoming very scarce in the study area where villagers have to travel $5-10 \mathrm{~km}$ in search of water for their domestic and livestock consumption. Surface flow of rivers that feeds Lake Chad has dried up with their tributaries impounded both within Nigeria and in the neighbouring countries this has also contributed to the drying up of Lake Chad (Figure 1). Therefore groundwater management and monitoring in the Borno Basin is necessary.

\subsection{Overview of the Problem}

There are published and unpublished information which reveal that, some flowing artesian wells are no more flowing in many parts of the Chad Formation of Borno Basin with water level getting deeper every year. There are reductions in the piezometric flow head of the Middle and Lower artesian and sub artesian aquifers of Chad Formation every year. However there is no valid documentation to support this development. This study therefore,

* Corresponding author, tel: +234 8035177409 
intends to find out through measurements of existing water levels in hand dug wells tapping the Upper aquifer and boreholes tapping the Middle and Lower aquifers in the study area and assess the rate of decline of piezometric head.

\subsection{Aim and Objectives}

This work is aimed at establishing the present rate of decline in groundwater levels in the Chad Formation of Borno Basin through comparison of groundwater levels measurements for the years 2007, 2008, 2009, 2011, and 2012 done in this study with the groundwater levels data by previous researchers $[1,2]$.
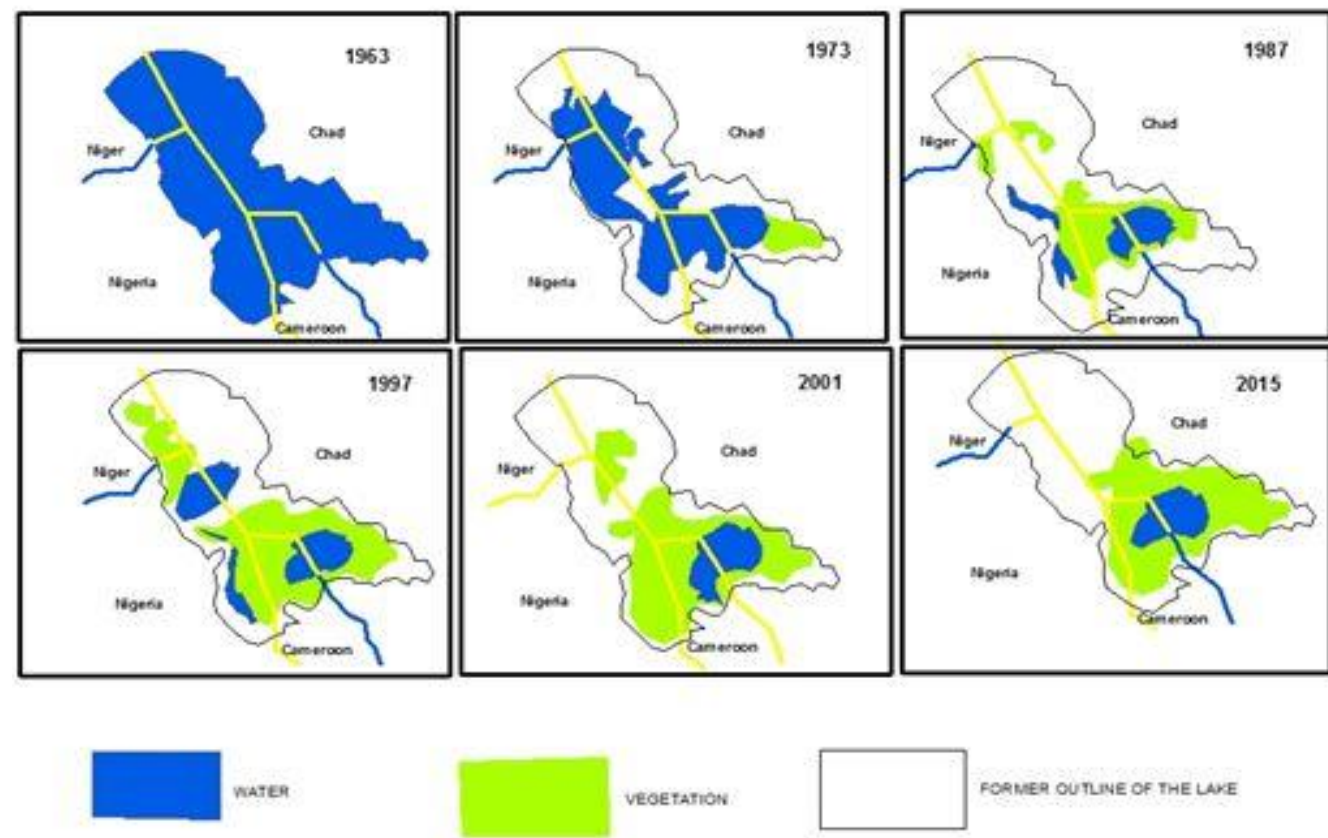

FRMER OUTMNE OF THE LANE

Figure 1: The receding Lake Chad (updated after Sara, 1963-2001 and Sani, 2015)

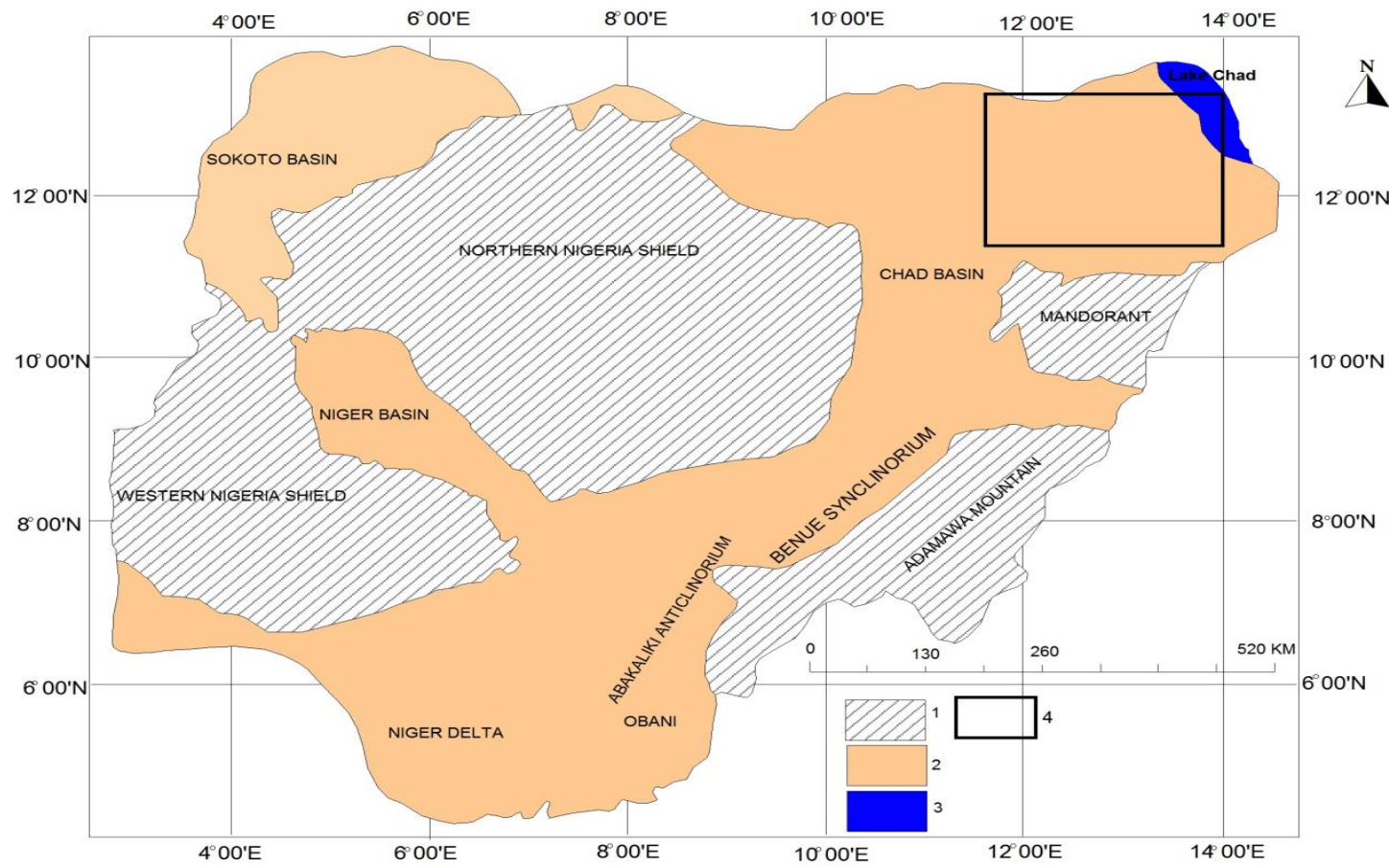

Figure 2: Location map of the study area (after NGSA, 2009) Explanation: 1-Basement complex rock; 2Sedimentary rock; 3- Lake Chad in 1953; and 4-The study area 


\section{MATERIALS AND METHOD}

The methodology employed in this study involved three stages; the first part is the desk study, followed by the field work and evaluation of the field data.

The desk study involved the assemblage of field equipment and collection of all available information such as topographic map of the study area, (Sheet 4 on a scale of 1:500,000 from Borno State Land and Survey Maiduguri). The topographic map is the fifth edition prepared in 2009 by the Nigerian geological Survey [3] the map was used as a base map for construction of location of hand dug wells position, construction of hydrogeological maps, as well as drainage map. Other tools include: Satellite navigator, (GPS), field notebook, writing materials and colour chat, water level indicator and metric tape,

Reconaincanse field work were carried out during 2006 and followed with detail field work in 2007 2008, 2009, 2011 and 2012 at the end of both wet and dry season covering a period of five years of monitoring the water level. The work involved locating position and coordinate of the hand dug wells mapped using hand-held Satellite Navigator (model Garmin accuracy $\pm 8 \mathrm{~m}$ ). Metric measuring tape and Heron Instrument Dipper-T600rT meter were also collected for measuring water level depth in hand dug wells (Figure 3 ).

During the field work, 87 hand dug wells tapping the Upper aquifer were measured during peak of dry season in April 2007, 2008, 2009, 2011 and 2012. While for the peak of the wet season, the water level was measured in August 2007 and 2012 for two years using an improved mechanical sounder and metric tape. The depth to the water level was then read directly from the tape after compensating for the height above the ground surface of the rim on which the reference points was marked. After the water level measurements were recorded in the field note book, the values are subtracted from the values of elevation of each hand dug wells measured on the field to have a water table elevation values where it is then plotted on topographical map to have hydrogeological map of the groundwater level and depletion map was constructed from the value measured in 2012 subtracted from the values of measurement in 2007. In deeper hand dug wells, lifting of water to the surface is difficult, thus a combined effort of human and animal is used to lift the groundwater to the surface with large leather container.

\section{LOCAL GEOLOGIC SETTING AND STRATIGRAPHY OF THE STUDY AREA}

The Chad Basin has its history beginning from the Upper Cretaceous probably uppermost Albian when over 1,000 m of continental sediments constituting the Bima Sandstone were deposited unconformably on the Pre- Cambrian basement (Figure 4). This sediment was designated as Pre-Bima by Avbovbo et al. [4]. The Bima Sandstone is overlain conformably by the transitional Gongila Formation. It consists of basal limestone overlain by sandstone/shale sequence. The limestone is rich in ammonites and mollusca. The assemblage of which indicates an early Turonian age. The formation has a maximum thickness of about $420 \mathrm{~m}$. Overlying the Gongila Formation is Fika Shale consisting of blue-black shale which is occasionally gypsiferous with intercalations of thin persistent limestone [5]. The fossils in the Fika Shale's are mainly fish remains, chameleon's fragments and the reptilian remains thus ascribing a Senonian to Maastrichtian age to the rock.

The Fika Shales appear to have been deposited under a submerged (transgressive) environment and overlain conformably by the Gombe Formation which is a continental sequence of estuarine and deltaic sediments deposited over the marine shales. Lenses of siltstone and mudstone occur with ironstone at the lower beds, while the middle part is characterized by well-bedded sandstone [5] The upper part of the formation contains poor quality coals and is represented by cross-bedded sandstone. The Gombe Sandstone is thought to be Maastrichtian in age. The end of the Cretaceous was marked by a period of uplift and erosion. The first deposits in the Nigeria sector of the basin after the Cretaceous period is the loosely cemented coarse to fine-grained sandstone of the Kerri-Kerri Formation. Massive clay stone and siltstone with bands of ironstone and conglomerate occur locally. The sandstone is often cross bedded and lignite (low grade coal) occurs near the base of the formation. The Kerri-Kerri Formation rests uncomfortably on the Gombe Sandstone.

Angular unconformity was thought to exist between the Cretaceous and the Neocene sediments. The Kerri-Kerri Formation is of Paleocene age and its environment of deposition is lacustrine or fluviolacustrine. 


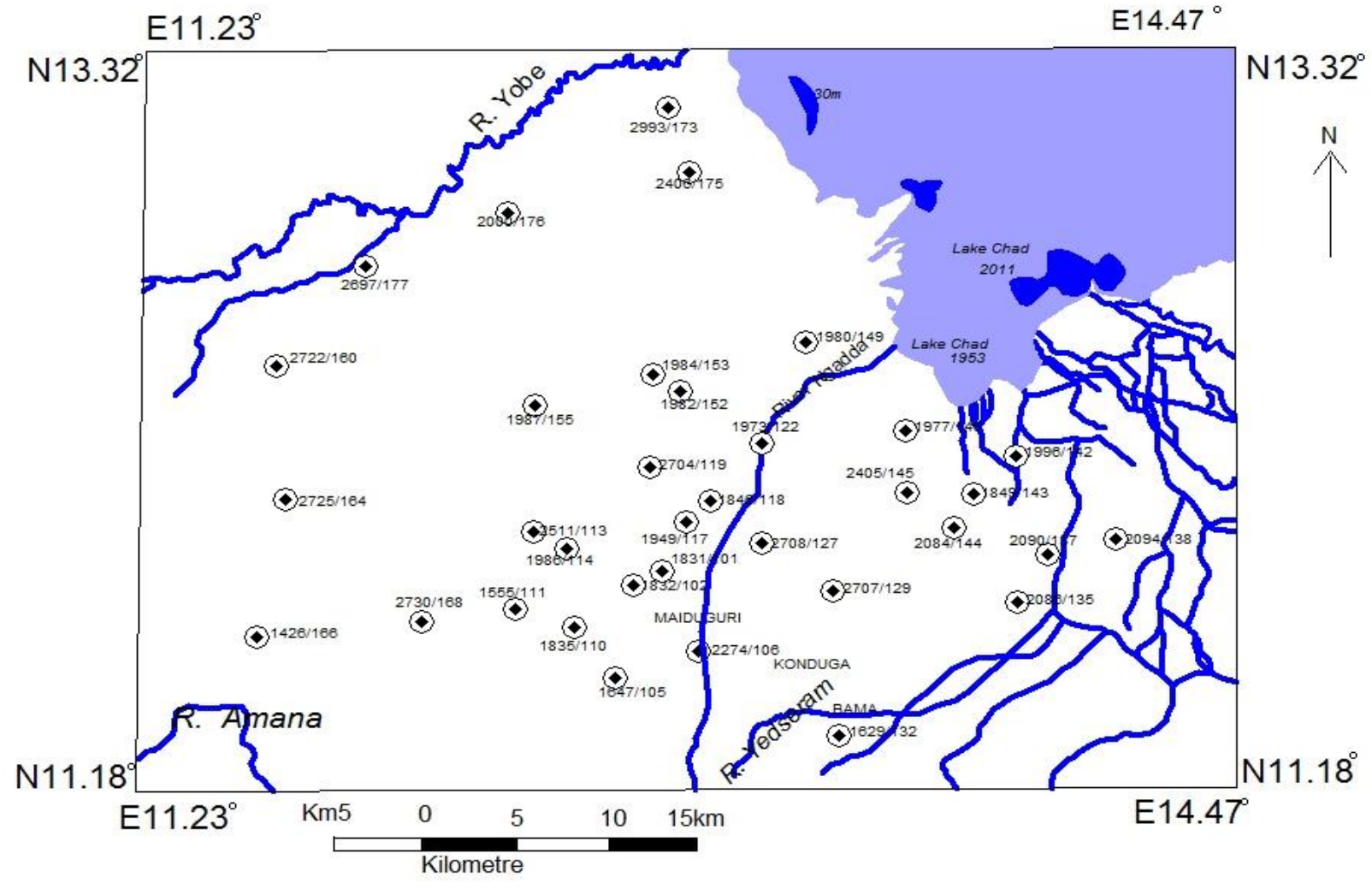

KEY :

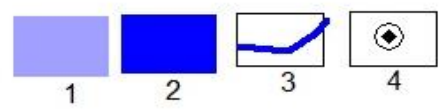

Figure 3: Drainage map and distribution of the studied hand dug wells Explanation: 1-Lake Chad in 1953 in light blue; 2-Lake Chad in 2011 in Dark blue; 3-River channels and 4- Hand dug wells

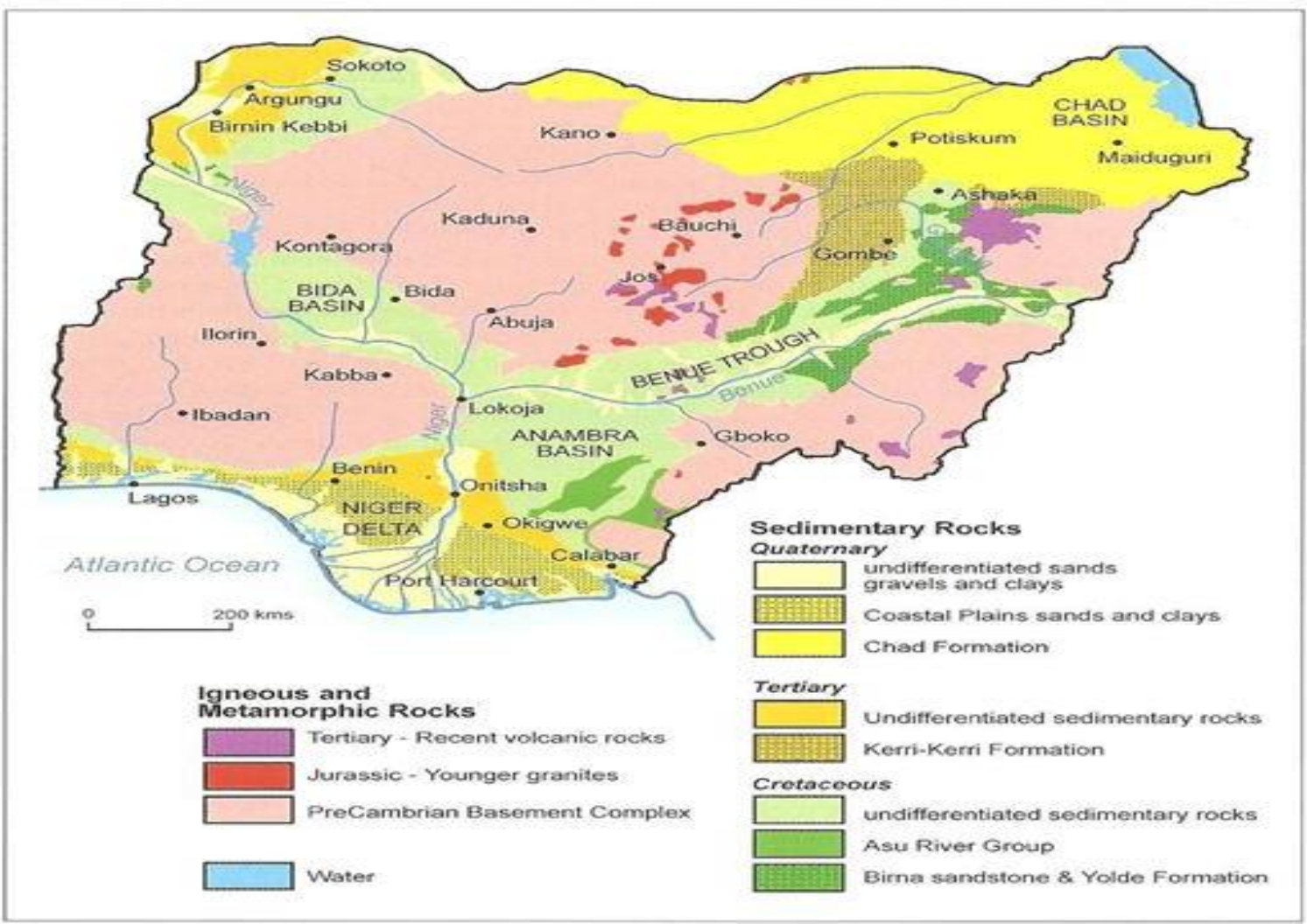

Figure 4: Generalized Geological Map of Nigeria (after MacDonald et al., 2005) [10] 
Chad Formation is of late Pliocene to Recent age. It consists of fine to coarse grained sand, blue-grey with intercalation of sandy clay, clay and diatomite. The sandy sediments are often poorly sorted. Borehole data show that the formation gently dips towards the centre of the basin. Maximum thickness of about $840 \mathrm{~m}$ has been recorded in the western shore of the Lake Chad. In more recent times, Aeolian sands accumulated in the Chad Basin and several ancient dunes may be recognized. The youngest deposits are the river alluvium and deltaic and lagoonal clay-flats that blanket wide areas to the south and southwest of Lake Chad [6].

\subsection{Hydrology and hydrogeologic setting of the study area}

The hydrology of the Borno Basin consists of atmospheric, surface and groundwater system. The rainfall is dependent on the climate of the area where the intensity of rainfall progressively reduces from southern to the northern part of study area. [7]. While Schoeneich [8] presents the map of depth of rainfall distribution in Nigeria (Figure 5) from the map it can be seen that the study area falls within Sahel climatic zone with an isohyet of $600 \mathrm{~mm} / \mathrm{a}$. This means that, depth of rainfall in the study area is less than $700 \mathrm{~mm} / \mathrm{a}$ according to Schoeneich, [8]. There is apparently no enough recharge taking place to replace the exploited groundwater in the study area because Lake Chad itself is no longer visible on the Nigerian map as it has already dried up.
Lake Chad, as the only source of perennial surface water located within the study area is receding from its normal size compared to 1963 . In respect of the socioeconomic context of Borno Basin, about 30 million people settled around the Lake Chad Basin for fishing, farming and livestock grazing. However, in the last thirty years, water demand for irrigation has greatly increased thus leading to over exploitation of the resource. In the rural areas, most people obtain water directly from ponds during rainy season or from available hand dug wells during dry period, while in cities where population is dense groundwater is also the main source of water supply for domestic and livestock uses. However, groundwater resource is becoming scarce and thus forcing many villagers to migrate close to available water points.

According to Barber and Jones, [1] the Chad Formation is separated into three aquiferous zones namely Upper, Middle and Lower aquifers. The Upper aquifer is unconfined and semi confined, while the Middle and Lower zone aquifers are confined.

The Middle aquifer consists mostly of fine to medium grained sand sandwiched between silty and clayey part of Chad Formation at depth of about $250 \mathrm{~m}$ with average thickness of about $50 \mathrm{~m}$. The Lower aquifer encountered in Maiduguri, Gudumbali, Kukawa and Monguno area ranges in depth from $250 \mathrm{~m}$ to $500 \mathrm{~m}$ depending on the local geology as shown in (Figure $6)$.

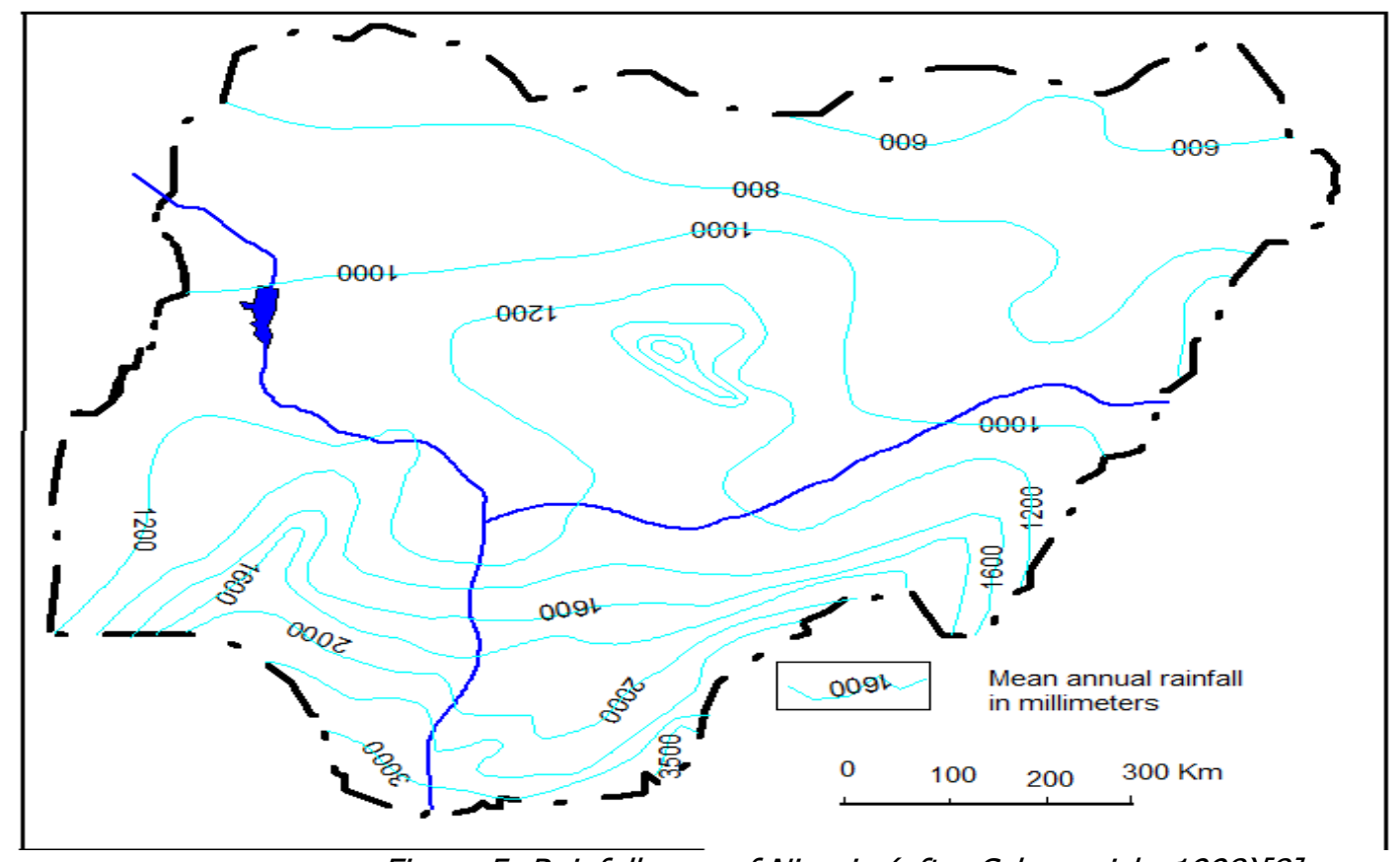

Figure 5: Rainfall map of Nigeria (after Schoeneich, 1998)[8] 


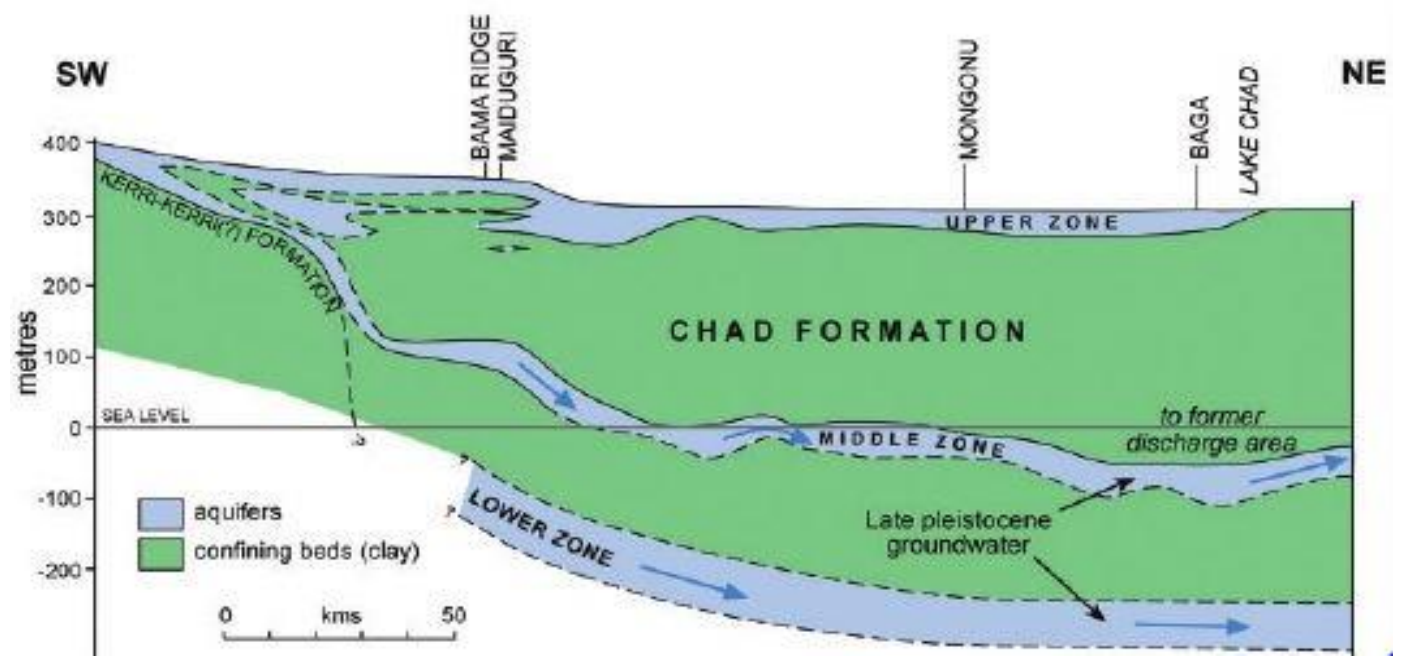

Figure 6: Cross-section of the Chad Formation from Damboa to Lake Chad (Modified after Barber and Jones, 1960) [1]

\section{RESULTS AND DISCUSSION}

Groundwater tapping Upper aquifer using hand dug wells were measured for this study, the Upper aquifer is separated into $A$ sub-zone which range from 1-10 $\mathrm{m}$ depth to water level, $\mathrm{B}$ sub-zone range from $10-60 \mathrm{~m}, \mathrm{C}$ subzone ranges from $60-100 \mathrm{~m}$ [9]. The results can be deduced to show that, $A$ and $B$ sub-zones are receiving thier recharge from vertical infiltration of rainfall and influent flow from Yobe, Ngadda and Yedseram rivers, although some wells close to the river banks have higher values, these show that water level is deeply tapped from C sub-zones. Therefore it can be deduced that, shallow wells are recharged by the rivers and deeper wells are not recharged by the rivers as can be seen in (Figure 6). The deeper $\mathrm{C}$ sub-zone was not receiving from either the rainfall or horizontal inflow from any river these wells have higher values as can be seen on depletion map in (Figure 7). Most of these wells are located around north-western part of these study area. Also it is clearly presented on the Figure $8 \mathrm{a}$ and $9 \mathrm{~b}$ plot of water level in dry and wet season measured from 2007 to 2012. From the plot it can be read that, from 1 to $30 \mathrm{~m}$ represent the " $\mathrm{A}$ " subzones; 30 to $60 \mathrm{~m}$ represent the " $B$ " sub-zones while 60 to $100 \mathrm{~m}$ represent the " $C$ " sub-zones with clear fluctuations from the plot and decline from 60 to 100 $\mathrm{m}$ both in dry and wet season.

\subsection{Map of comparison of depletion of piezometric surface tapping Middle and Lower aquifer.}

The map is prepared by selecting three boreholes, one at Sabsawa, Gajibo and Dalori all tapping Middle and Lower aquifers. The three boreholes were measured by Barber and Jones [1] where he recorded values of water level of $+5.8 \mathrm{~m}$ in Dalori, $+12.5 \mathrm{~m}$ in Sabsawa and $+12.5 \mathrm{~m}$ in Gajibo followed by Camalt and Tibbits [2] where they recorded $-18.2 \mathrm{~m}$ of water level at well Dalori, +3.9 $\mathrm{m}$ at well Sabsawa and $+10.2 \mathrm{~m}$ at well Gajibo. During this research these wells were measured in 2007 and 2012 respectively as presented in the Table 1.

\subsection{Comparison with the previous works}

The present work was compared with Barber and Jones, [1] measurement. From the 80 boreholes measured in the present study, 35 boreholes were measured by Barber and Jones [1] and were compared with the present measurements. A comparison of the results of measurements: +25.9 to $-46.6 \mathrm{~m}$ in $1960,+1.5$ to $-57.8 \mathrm{~m}$ and in 2007 +1.4 to $-65.3 \mathrm{~m}$ in 2012. Table 2 shows results of water level measurements in 2007 and 2012 compared with that of Barber and Jones,[1] measurements and plot of water level relative to borehole location in each successive year of this study is presented in Figure 9. The graph of water level elevation map constructed shows clearly difference in water level from 1960 to 2007 and 2012. The graph shows a depleting groundwater level since 1960 to 2012. Therefore it can be deduced that water level is falling in the Chad Formation, the groundwater resource need to be managed prudently, else the study area will be under catastrophic water problems for domestic, livestock and small scale irrigation needs. If the 
water is completely mined out in the Formation, hydro compaction may likely take place due to closure of pore spaces by geostatic pressure in the Formation.

\subsection{Reason for the water level decline in the Borno Basin}

From the available results of field measurements, the decline in the deeper $\mathrm{C}$ zone tapping Upper aquifer and the piezometric head loss in the Middle and Lower aquifers can be attributed to the following reasons: There is no recharge taking place at the $c$ and $d$ sub-zone in the Upper aquifer and in the Middle and Lower aquifers. The research area fall within Sahel climatic belt of Nigeria, Sahel drought have affected the basin for lack of sufficient rainfall which has reduced infiltration to recharge this aquifer leading to the depleting groundwater level. Another reason is that, since these boreholes were drilled in 1960 by the Government of Northern region they were not capped, water continue to flow to the ground surface for 24 hours daily without sustaining pressure head and is still flowing to the surface, this leads to decline in piezometric head. Discharge rate from the aquifer is higher than the recharge rate. Since rate of abstraction of this groundwater by the users is higher, it greatly contributes to depleting groundwater level in the basin. Rivers that are flowing towards Lake Chad were already blocked and impounded by dam reservoirs for small scale irrigation and for domestic supply to urban cities which affected the recharge of both surface flow and groundwater.

Table 1: Comparative results of water level measurements in 1960, 1965, 2007 and 2012

\begin{tabular}{cccc}
\hline Years of & \multicolumn{3}{c}{ Name of Locality } \\
\cline { 2 - 4 } measurements & Dalori & Sabsawa & Gajibo \\
\hline 1960 & +5.8 & +12.5 & +12.5 \\
1965 & $-18.2 \mathrm{~m}$ & $+3.9 \mathrm{~m}$ & $+10.2 \mathrm{~m}$ \\
2007 & $-36.2 \mathrm{~m}$ & $-4.0 \mathrm{~m}$ & $+1.2 \mathrm{~m}$ \\
2012 & $-43.2 \mathrm{~m}$ & $-6.8 \mathrm{~m}$ & $+0.3 \mathrm{~m}$ \\
Aquifers & Middle & Middle & Lower \\
\hline
\end{tabular}

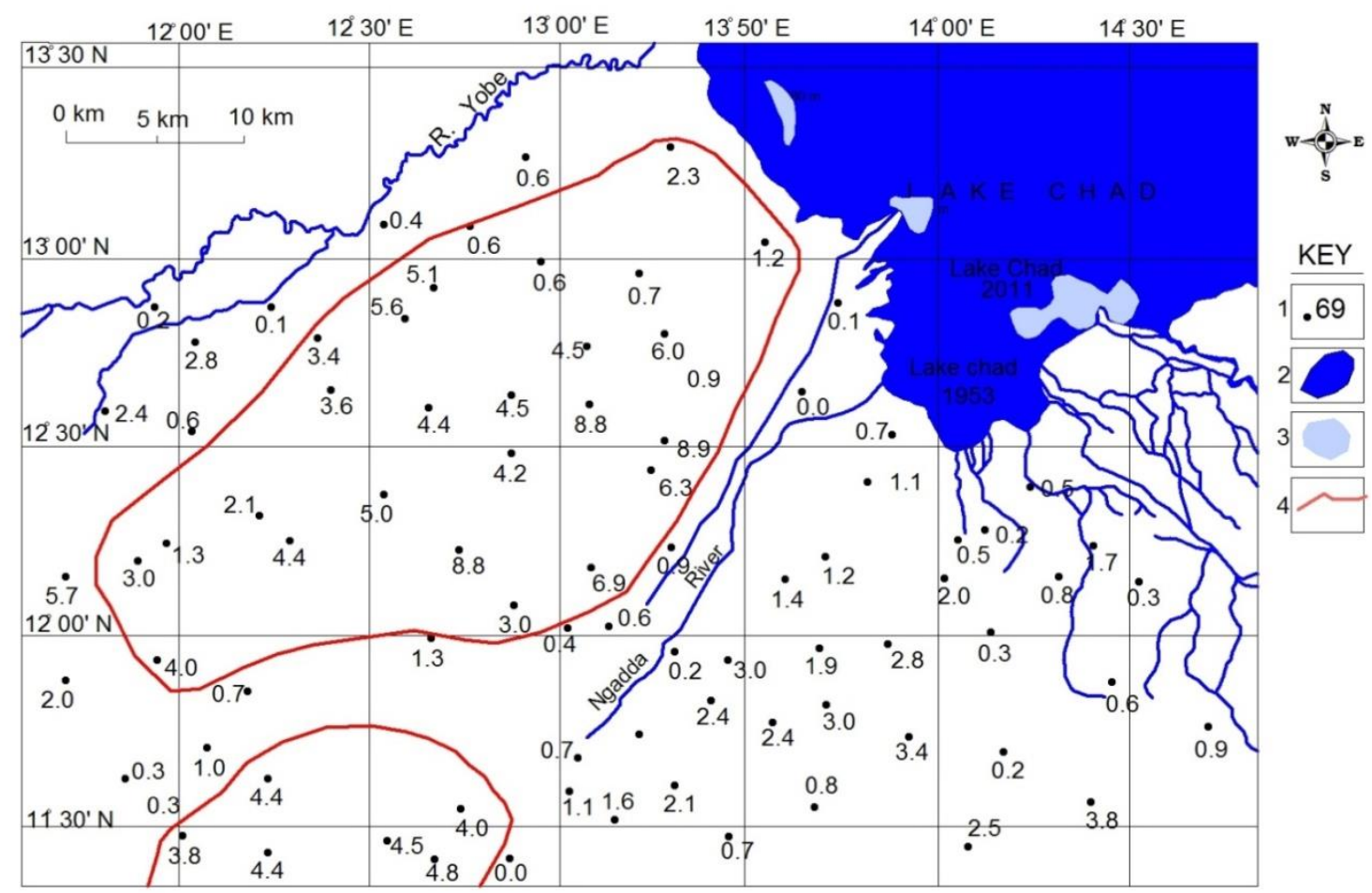

Figure 7: Map of water level changes of groundwater in the Upper aquifer intheChad Formation.Explanation: 1Depletion values in hand dug wells; 2- Lake Chad in 1953 in dark blue; 3- Remnants of LakeChad in 2011 in light blue; 4- Areas with high rate of depletion tapping C sub-zones in Upper aquifer of Chad Formation 


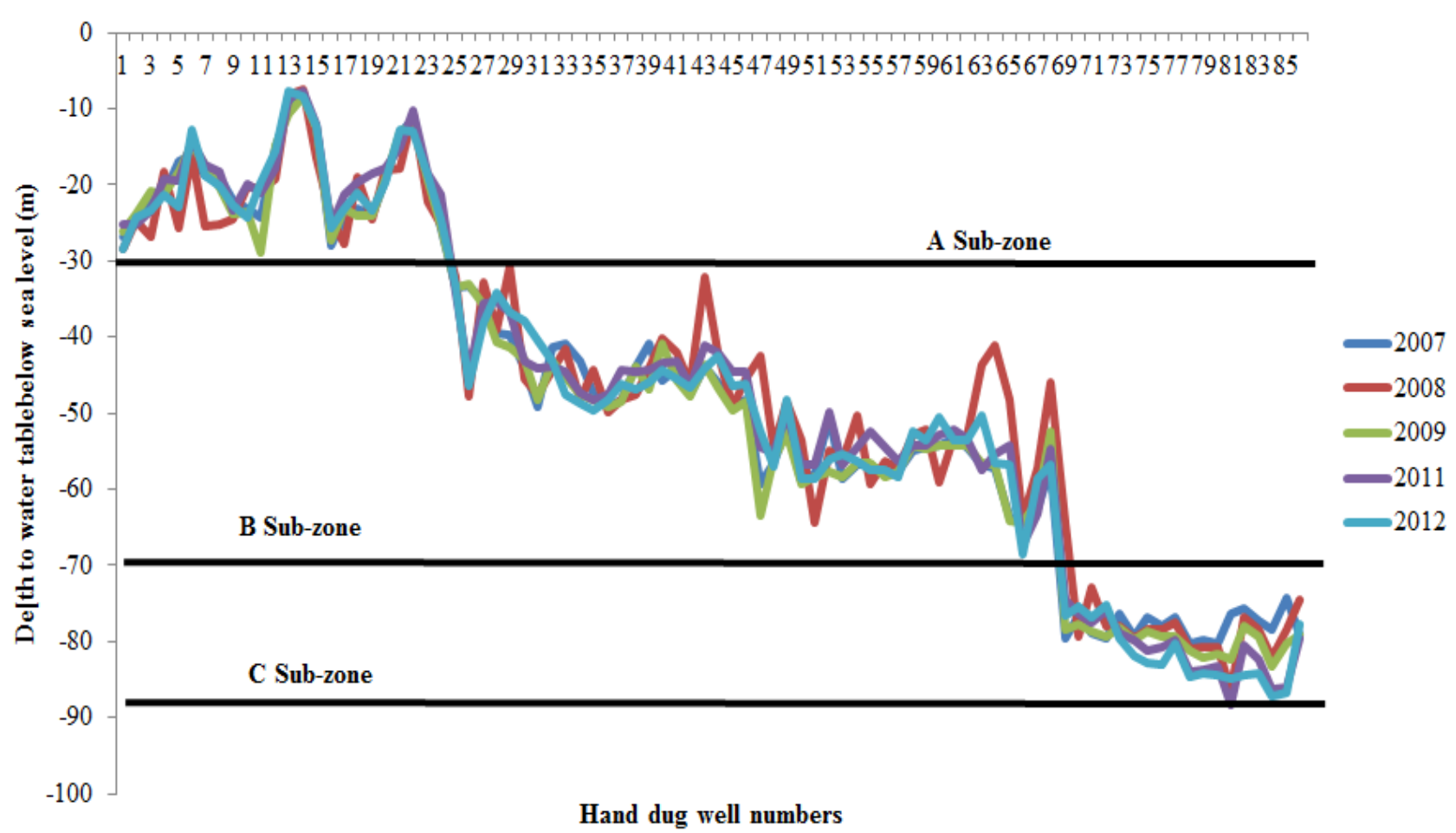

Figure 8a: Plots of dry season depth to water level Upper aquifer

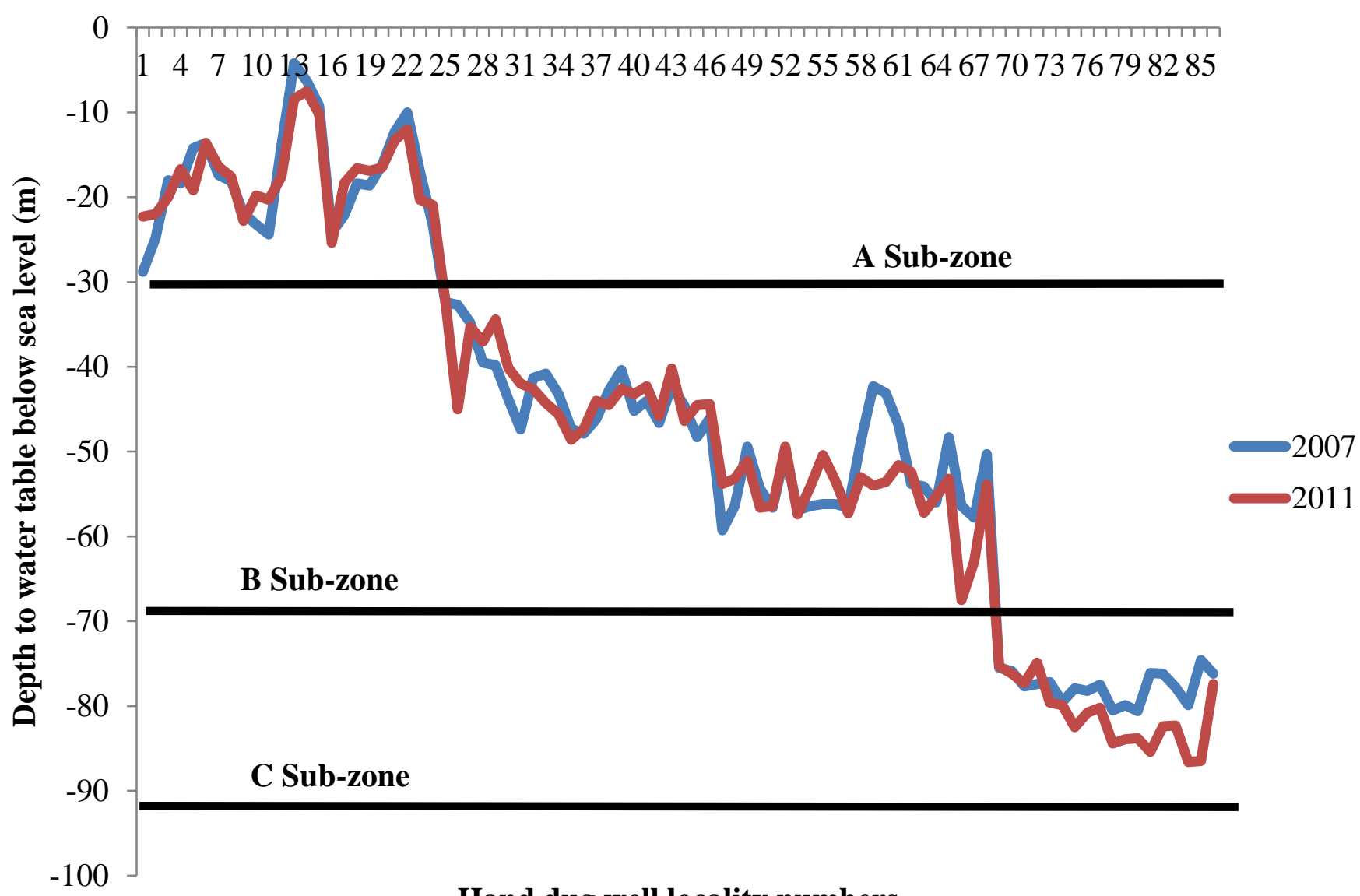

Hand dug well locality numbers

Figure 8b: Plots of dry season depth to water level Upper aquifer 
Groundwater Depletion in the Upper Aquifer of the Chad Formation, Chad Basin, North-Eastern Nigeria, S. Adamu, et al

Table 2: Groundwater depletion in hand-dug wells measured from 2007 to 2012 (mbgl) tapping Upper aquifer.

\begin{tabular}{|c|c|c|c|c|c|c|c|c|c|c|c|c|}
\hline \multirow{2}{*}{$\begin{array}{l}\mathrm{S} / \\
\mathrm{N}\end{array}$} & \multirow[t]{2}{*}{ Locality } & \multicolumn{3}{|c|}{ Coordinates (Minna Datum) magl } & \multicolumn{8}{|c|}{ Year of measurement (mbsl) } \\
\hline & & Latitude & Longitude & $\begin{array}{l}\text { Elevati } \\
\text { on in } \\
\text { masl }\end{array}$ & $\begin{array}{l}\text { Dry } \\
\text { Season } \\
14-26 / 4 / \\
2007\end{array}$ & $\begin{array}{l}\text { Wet } \\
\text { Season } \\
15-29 / 8 / \\
2007\end{array}$ & $\begin{array}{l}\text { Dry } \\
\text { Seaso } \\
n \\
8-28 / 4 / \\
2008\end{array}$ & $\begin{array}{l}\text { Dry } \\
\text { Season } \\
15-25 / 4 / \\
2009\end{array}$ & $\begin{array}{l}\text { Dry } \\
\text { Season } \\
15-24 / 4 / \\
2011\end{array}$ & $\begin{array}{l}\text { Wet } \\
\text { Season } \\
20-27 / 8 / \\
2011\end{array}$ & $\begin{array}{l}\text { Dry } \\
\text { Seaso } \\
n \\
8-27 / 1 / \\
2012\end{array}$ & $\begin{array}{l}\text { Dry } \\
\text { Season } \\
\text { Depletion } \\
2007 / 201 \\
2\end{array}$ \\
\hline 1 & Jiddari & 11043.592' & 13013.841' & 322 & -26.8 & -28.8 & -28.5 & -26.1 & $-25,2$ & -22.3 & -28.5 & 1.7 \\
\hline 2 & $\begin{array}{l}\text { Gazamala } \\
\text { Algeri }\end{array}$ & $12^{0} 40.812^{\prime}$ & 13023.748' & 271 & -25.1 & -24.8 & -24.8 & -23.9 & -25.3 & -22.0 & -24.2 & 0.9 \\
\hline 3 & Mongono & $12^{0} 39.776^{\prime}$ & 13037.608' & 284 & -21.4 & -18.0 & -26.8 & -20.9 & -23.3 & -20.0 & -23.4 & 0.0 \\
\hline 4 & Krison & $12^{053.511^{\prime}}$ & 13044.234' & 285 & -21.4 & -18.4 & -18.4 & -21.3 & -19.2 & -16.7 & -21.3 & 0.1 \\
\hline 5 & Asanti & $12^{0} 49.941^{\prime}$ & 13017.208' & 286 & -17.0 & -14.2 & -25.7 & -18.4 & -194 & -192 & -23.0 & 6.0 \\
\hline 6 & Baderi & $12^{032.054}$ & 13052.835 & 286 & -15.9 & -13.6 & -16.1 & -14.6 & -14.2 & -13.6 & -12.8 & 3.1 \\
\hline 7 & Duba & $12^{0} 22.380^{\prime}$ & 13049.631' & 290 & -18.8 & -17.4 & -25.4 & -17.3 & -17.3 & -16.4 & -18.8 & 0.0 \\
\hline 8 & Marte & 12024.677' & 13049.827' & 290 & -19.1 & -18.1 & -25.2 & -20.3 & -18.4 & -17.6 & -20.2 & 1.1 \\
\hline 9 & Dalwa & 11040.530' & 13004.182' & 327 & -21.9 & -21.9 & -24.5 & -23.9 & -23.3 & -22.8 & -22.6 & 0.7 \\
\hline 10 & MusbaAbbari & 11035.856' & $13^{0} 02.208^{\prime}$ & 342 & -23.2 & -23.2 & -20.2 & -23.7 & -20.0 & -19.8 & -24.3 & 1.1 \\
\hline 11 & Fulatari & $11^{0} 23.426^{\prime}$ & $12^{0} 41.888^{\prime}$ & 365 & -24.4 & -24.4 & -20.6 & -28.9 & -21.1 & -20.3 & -19.6 & 4.8 \\
\hline 12 & Kusur & 12033.483' & $12^{0} 04.572^{\prime}$ & 324 & -15.0 & -13.9 & -19.3 & -14.8 & -17.9 & -17.6 & -15.6 & 0.6 \\
\hline 13 & Gumsa & 12037.483' & 11048.324' & 327 & -10.1 & -4.2 & -8.1 & -10.8 & $-8,7$ & -8.4 & -7.7 & 2.4 \\
\hline 14 & Geidam & 12057.481' & 11059.463' & 311 & -8.4 & -6.3 & -7.6 & -8.3 & $-7,8$ & -7.5 & $--8,2$ & 0.2 \\
\hline 15 & Dajire & 12053.143' & $12^{015.314^{\prime}}$ & 319 & -12.4 & -9.2 & -16.5 & -12.6 & -12.1 & -10.2 & -12.3 & 0.1 \\
\hline 16 & Karirina & 13019.414' & 13018.314' & 303 & -27.9 & -24.2 & -24.4 & -27.3 & $-25,4$ & -25.4 & -25.6 & 2.3 \\
\hline 17 & Karigoa & $13^{0} 03.472^{\prime}$ & $13^{0} 33.578^{\prime}$ & 296 & -24.3 & -22.1 & -27.7 & -23.1 & -21.2 & -18.3 & -23.1 & 1.2 \\
\hline 18 & Mogolo & $12^{0} 09.391^{\prime}$ & $14000.401^{\prime}$ & 291 & -23.1 & -18.4 & -18.9 & -24.1 & -19.6 & -16.6 & -21.1 & 2.0 \\
\hline 19 & Logomani & 12014.196' & 14001.931' & 284 & -24.0 & -18.6 & -24.6 & -24.0 & -18.6 & -16.9 & -23.5 & 0.5 \\
\hline 21 & Missini & 12016.704' & $14^{0} 06.576^{\prime}$ & 291 & -19.4 & -16.2 & -18.1 & -19.3 & -17.8 & -16.5 & -19.6 & 0.2 \\
\hline 22 & $\begin{array}{l}\text { Gambaru } \\
\text { Ngala }\end{array}$ & $12^{024.008^{\prime}}$ & $14012.016^{\prime}$ & 285 & -13.2 & -12.3 & -17.8 & -13.0 & -15 & -13.3 & -12.7 & 0.5 \\
\hline 23 & Ntudu & $12^{014.414^{\prime}}$ & 14022.332' & 290 & -11.4 & -10.0 & -10.8 & -12.2 & -10.3 & -12.0 & -13.1 & 1.7 \\
\hline 24 & Mudu & $12^{0} 08.441^{\prime}$ & $14^{0} 17.217^{\prime}$ & 290 & -19.5 & -17.0 & -22.2 & -19.5 & -18.5 & -20.3 & -18.7 & 0.8 \\
\hline 25 & Komasa & 11031.414' & $13^{0} 08.337^{\prime}$ & 327 & -25.8 & -23.2 & -25.2 & -25.4 & -21.4 & -20.9 & -24.6 & 1.6 \\
\hline 26 & Kala & 12007.433' & 14029.349' & 292 & -33.5 & -32.4 & -32.2 & -33.5 & $-34,2$ & -32.2 & -33.2 & 0.3 \\
\hline 27 & Lungoa & 11037.176 & 11052.175 & 355 & -33.2 & -32.7 & -47.9 & -33.0 & -44.9 & -45.0 & -46.5 & 0.3 \\
\hline 28 & Dilawa & $12^{0} 47.392^{\prime}$ & $12^{0} 03.416^{\prime}$ & 335 & -35.4 & -34.8 & -32.8 & -35.9 & 35.6 & -35.3 & -38.2 & 2.8 \\
\hline 29 & Bundula & 11058.371 & $13052.141^{\prime}$ & 296 & -39.5 & -39.5 & -39.1 & -40.6 & -35.3 & -37.0 & -34.2 & 5.3 \\
\hline 30 & Limanti & 11055.092' & $13^{0} 27.481^{\prime}$ & 306 & -39.8 & -39.8 & -30.8 & -41.3 & -36.7 & -34.4 & -36.8 & 3.0 \\
\hline 31 & Tawai & $12^{027.374}$ & 13013.419' & 297 & -44.2 & -43.8 & -45.5 & -42.9 & $-43,3$ & -40.1 & -37.9 & 6.3 \\
\hline 32 & Goni Abachari & 12032.985' & 13017.049' & 291 & -49.3 & -47.4 & -47.6 & -48.3 & -44.1 & -42.0 & -40.4 & 8.9 \\
\hline 33 & Abbari & 11057.309' & 13039.481' & 300 & -41.3 & -41.3 & -44.4 & -43.1 & -44.0 & -42.6 & -43.2 & 1.9 \\
\hline 34 & Futchi Murtari & 11048.232' & 13041.629' & 307 & -40.8 & -40.8 & -41.6 & -45.3 & -44.6 & -44.3 & -47.5 & 6.7 \\
\hline 35 & Maimusari & 11045.316' & 13033.613' & 315 & -43.2 & -43.2 & -48.3 & -47.6 & -47.4 & -45.6 & -48.8 & 5.5 \\
\hline 36 & Loskuri & 11049.818' & $13^{0} 24.415^{\prime}$ & 312 & -47.3 & -47.3 & -44.3 & -48.3 & $-48,6$ & -48.6 & -49.7 & 2.4 \\
\hline 37 & Bulawa & 11043.284' & $12^{0} 07.313^{\prime}$ & 328 & -49.3 & -47.9 & -49.8 & -49.2 & -47.5 & -47.3 & $-48,3$ & 1.0 \\
\hline 38 & Gabalkamal & 11054.439' & 11043.612' & 331 & -48.3 & -46.2 & -48.2 & -48.5 & -44.4 & -44.0 & -46.3 & 2.0 \\
\hline 39 & Magumeri & 12005.573' & 12054.719' & 306 & -43.8 & -42.8 & -47.6 & -43.8 & -44.7 & -44.5 & -46.8 & 3.0 \\
\hline 40 & Oguru & 11057.321 & $13^{0} 18.561^{\prime}$ & 319 & -40.9 & -40.4 & -44.1 & -46.9 & -44.3 & -42.6 & -46.0 & 5.1 \\
\hline 41 & Gumna & $12^{0} 08.710^{\prime}$ & 13035.101' & 310 & -45.7 & -45.2 & -40.2 & -40.8 & -43.5 & -43.2 & -44.3 & 1.4 \\
\hline 42 & Bunduloa & $12^{012.341^{\prime}}$ & $13^{042.812^{\prime}}$ & 301 & -44.2 & -44.0 & -42.1 & -45.7 & -43.2 & -42.3 & -45.4 & 1.2 \\
\hline 43 & Mige & 12014.411' & 13017.315 & 299 & -47.6 & -46.6 & -46.3 & -47.8 & -46.4 & -45.8 & -46.7 & 0.9 \\
\hline 44 & Mallam Mala & 11059.432' & 14006.931' & 294 & -43.9 & -42.2 & -32.1 & -43.7 & -41.2 & -40.2 & -44.2 & 0.3 \\
\hline 45 & Binguda & 11042.842' & 13053.491' & 291 & -45.9 & -44.6 & -42.1 & -46.6 & -42.1 & $-40,0$ & -42.5 & 3.4 \\
\hline 46 & Kate & 11024.729' & $14^{0} 02.812^{\prime}$ & 290 & -48.9 & -48.3 & -49.2 & -49.6 & -44.6 & -44.5 & -46.4 & 2.5 \\
\hline 47 & Kasugula & 11036.272' & 13019.412' & 308 & -48.3 & -46.1 & -45.6 & -48.4 & -44.7 & -44.4 & -46.2 & 2.1 \\
\hline 48 & Ali Jomari & 11033.748' & $12^{0} 45.734^{\prime}$ & 365 & -59.3 & -59.3 & -42.4 & -63.5 & -54.6 & -53.8 & -52.5 & 5.8 \\
\hline 49 & Chubbal & 11053.996' & $13^{0} 04.226^{\prime}$ & 318 & -56.6 & -56.4 & -54.5 & -56.1 & -55.2 & -53.2 & -57.1 & 0.5 \\
\hline 50 & Limusri & 11028.413' & $13^{0} 03.614^{\prime}$ & 355 & -52.0 & -49.4 & -48.6 & -52.6 & -50.2 & -51.1 & -48.2 & 3.8 \\
\hline 51 & Girbua & $11^{033.815}$ & $12^{0} 02.073^{\prime}$ & 312 & -59.0 & -54.4 & -53.6 & -59.3 & -56.8 & -56.6 & -58.7 & 0.3 \\
\hline 52 & Debugu & $11052.014^{\prime}$ & $12^{011.437^{\prime}}$ & 330 & -57.9 & -56.6 & -64.4 & -58.4 & -56.7 & -56.4 & -58.6 & 0.7 \\
\hline 53 & Babangida & $12^{0} 09.213^{\prime}$ & 11046.197' & 319 & -50.5 & -50.0 & $-54 . .9$ & -57.7 & -49.8 & -49.4 & -56.2 & 5.7 \\
\hline 54 & Sakanaram & $11059.415^{\prime}$ & $12^{0} 40.221^{\prime}$ & 325 & -58.7 & -56.9 & -56.3 & -58.5 & -56.8 & -57.4 & -55.3 & 1.3 \\
\hline 55 & Fadram & 12001.433' & $13^{0} 01.721^{\prime}$ & 327 & -56.8 & -56.4 & -50.3 & -56.5 & -54.4 & -54.1 & -56.4 & 0.4 \\
\hline 56 & Doli & $12^{0} 01.781^{\prime}$ & $13^{0} 08.432^{\prime}$ & 325 & -56.8 & -56.2 & -59.4 & -56.6 & -52.5 & -50.4 & -57.4 & 0.6 \\
\hline 57 & Jumami & 12058.423' & 13014.394' & 297 & -58.2 & -56.2 & -56.4 & -58.3 & -54.6 & -53.5 & -57.5 & 0.7 \\
\hline
\end{tabular}




\begin{tabular}{|c|c|c|c|c|c|c|c|c|c|c|c|c|}
\hline \multirow{2}{*}{$\begin{array}{l}\mathrm{S} / \\
\mathrm{N}\end{array}$} & \multirow[t]{2}{*}{ Locality } & \multicolumn{3}{|c|}{ Coordinates (Minna Datum) magl } & \multicolumn{8}{|c|}{ Year of measurement (mbsl) } \\
\hline & & Latitude & Longitude & $\begin{array}{l}\text { Elevati } \\
\text { on in } \\
\text { masl }\end{array}$ & $\begin{array}{l}\text { Dry } \\
\text { Season } \\
14-26 / 4 / \\
2007\end{array}$ & $\begin{array}{l}\text { Wet } \\
\text { Season } \\
15-29 / 8 / \\
2007\end{array}$ & $\begin{array}{l}\text { Dry } \\
\text { Seaso } \\
n \\
8-28 / 4 / \\
2008\end{array}$ & $\begin{array}{l}\text { Dry } \\
\text { Season } \\
15-25 / 4 / \\
2009\end{array}$ & $\begin{array}{l}\text { Dry } \\
\text { Season } \\
15-24 / 4 / \\
2011\end{array}$ & $\begin{array}{l}\text { Wet } \\
\text { Season } \\
20-27 / 8 / \\
2011\end{array}$ & $\begin{array}{l}\text { Dry } \\
\text { Seaso } \\
n \\
8-27 / 1 / \\
2012\end{array}$ & $\begin{array}{l}\text { Dry } \\
\text { Season } \\
\text { Depletion } \\
2007 / 201 \\
2\end{array}$ \\
\hline 58 & Baradi & $13^{0} 00.423^{\prime}$ & $12^{057.394}$ & 301 & -57.7 & -56.6 & -57.3 & -57.8 & -56.3 & $-57,3$ & -58.3 & 0.6 \\
\hline 59 & Duguma & 11051.241' & 14026.824' & 291 & -55.0 & -48.9 & -52.9 & -54.3 & -54.2 & -53.0 & -52.4 & 2.6 \\
\hline 60 & Segege & 11043.710' & 14039.192' & 290 & -54.4 & -42.3 & -52.2 & -54.7 & -54.3 & -54.0 & -53.5 & 0.9 \\
\hline 61 & Hurriya & 11031.327' & 14021.192' & 291 & -54.3 & -43.1 & -59.0 & -54.3 & -52.8 & -53.6 & -50.5 & 3,8 \\
\hline 62 & $\begin{array}{l}\text { Gulumba } \\
\text { Gana }\end{array}$ & $11^{0} 40.821^{\prime}$ & $14^{0} 08.741^{\prime}$ & 292 & -53.3 & -46.9 & -53.1 & -54.3 & -52.2 & -51.6 & -53.5 & 0.2 \\
\hline 63 & Bama & 11031.463' & $13040.814^{\prime}$ & 372 & -54.4 & -53.8 & -53.1 & -54.2 & -53.4 & -52.4 & -53.6 & 0.8 \\
\hline 64 & Orga & 11026.427' & $13^{0} 26.814^{\prime}$ & 340 & -56.9 & -54.1 & -43.6 & -56.5 & -57.6 & -57.2 & -50.4 & 6.5 \\
\hline 65 & Zari & 13006.502' & 12046.313' & 305 & -57.2 & -56.0 & -41.2 & -56.9 & -55.4 & -55.3 & -56.6 & 0.6 \\
\hline 66 & Dunamari & $11025.549^{\prime}$ & $12^{015.392}$ & 328 & -63.8 & -48.3 & -48.3 & -64.1 & -54.3 & -53.2 & -56.8 & 7.0 \\
\hline 67 & Gotomba & 11037.671' & 12016.671' & 350 & -64.2 & -56.4 & -63.9 & -64.3 & -67.3 & -67.5 & -68.6 & 4.4 \\
\hline 68 & Kalalawa & 11056.240' & $11050.435^{\prime}$ & 318 & -62.6 & -57.8 & -57.3 & -61.7 & -63.2 & -63.0 & -58.6 & 4.0 \\
\hline 69 & Sigoga & 13017.613' & $12^{055.331^{\prime}}$ & 303 & -57.3 & -50.3 & -45.9 & -52.4 & -54.7 & -53.9 & -56.7 & 0.6 \\
\hline 70 & Ningilam & $12^{0} 12.726^{\prime}$ & 11055.277' & 311 & -79.5 & -75.5 & -64.4 & -78.4 & -74.6 & -75.3 & -76.5 & 3.0 \\
\hline 71 & Godurom & 12014.188' & 11059.623' & 340 & -76.7 & -75.9 & -79.4 & -77.8 & -76.4 & -76.2 & -75.4 & 1.3 \\
\hline 72 & Dumburum & 12020.394' & 12014.419' & 347 & -78.9 & -77.7 & -73.0 & -78.6 & -77.5 & -77.3 & --76.8 & 2.1 \\
\hline 73 & Mangugum & 12015.391' & 12019.439' & 336 & -79.7 & -77.4 & -78.0 & -79.4 & -76.0 & -74.9 & $7-5.3$ & 4.4 \\
\hline 74 & Futchimiran & 12050.413' & 12022.312' & 306 & -76.3 & -77.2 & -77.9 & -78.3 & -79.0 & -79.6 & -79.7 & 3.4 \\
\hline 75 & Ngelewa & $12^{0} 40.613^{\prime}$ & $12^{0} 24.317^{\prime}$ & 327 & -79.4 & -79.5 & -79.6 & -79.8 & -79.9 & $-79,9$ & -82.0 & 3.6 \\
\hline 76 & Kokodi & 12052.319' & $12^{036.411^{\prime}}$ & 283 & -76.9 & -77.9 & -78.5 & -78.7 & -81.2 & -82.5 & -82.8 & 5.6 \\
\hline 77 & Dudu & 12057.812' & $12^{0} 40.314^{\prime}$ & 311 & -77.9 & -78.2 & -78.4 & -79.3 & -80.7 & -80.8 & $-83,0$ & 5.1 \\
\hline 78 & Damasack & 13006.313' & 12032.716' & 325 & -76.8 & -77.5 & $-77 ; 6$ & -79.4 & -79.9 & -80.0 & $-80 . .2$ & 3.4 \\
\hline 79 & Mellaram & 12039.117' & 12053.132' & 307 & -80.2 & -80.5 & -80.9 & -81.3 & -84.0 & $-84,4$ & $-84,7$ & 4.5 \\
\hline 80 & Doili & 12037.124' & $12^{0} 40.335^{\prime}$ & 301 & -79.9 & -79.9 & -80.8 & -82.1 & -83.8 & -83.9 & -84.3 & 4.4 \\
\hline 81 & Kingoa & $12^{0} 28.135^{\prime}$ & $12^{0} 53.319^{\prime}$ & 302 & -80.3 & -80.6 & -80.8 & -81.7 & -83.4 & -83.8 & -84.5 & 4.2 \\
\hline 82 & Yesku & 12023.314' & $12^{0} 32.419^{\prime}$ & 302 & -59.9 & -56.8 & -56.9 & -58.9 & -58.3 & -56.5 & -54.9 & 5.0 \\
\hline 83 & Furam & $12^{0} 14.712^{\prime}$ & $12^{0} 45.417^{\prime}$ & 326 & -75.6 & -76.2 & -76.8 & -77.9 & -80.6 & -82.4 & -84.4 & 8.8 \\
\hline 84 & Morowa & $12^{010.532}$ & $13^{0} 05.613^{\prime}$ & 317 & -77.4 & -77.8 & -78.4 & -79.4 & -82.4 & -82.3 & -84.3 & 6.9 \\
\hline 85 & Sabsawa & $12^{037.411^{\prime}}$ & $13^{0} 05.814^{\prime}$ & 300 & -78.4 & -79.9 & -82.2 & -83.4 & -86.4 & -86.6 & -87.2 & 8.8 \\
\hline 86 & Mayo & 12047.313' & 13004.714' & 297 & -74.2 & -74.6 & -78.5 & -80.4 & -86.1 & -86.5 & -86.7 & 0.5 \\
\hline 87 & Galengi & 11027.591' & 12033.599' & 346 & -79.2 & -76.2 & -74.6 & -79.2 & -79.6 & -77.4 & -77.8 & 1.4 \\
\hline
\end{tabular}

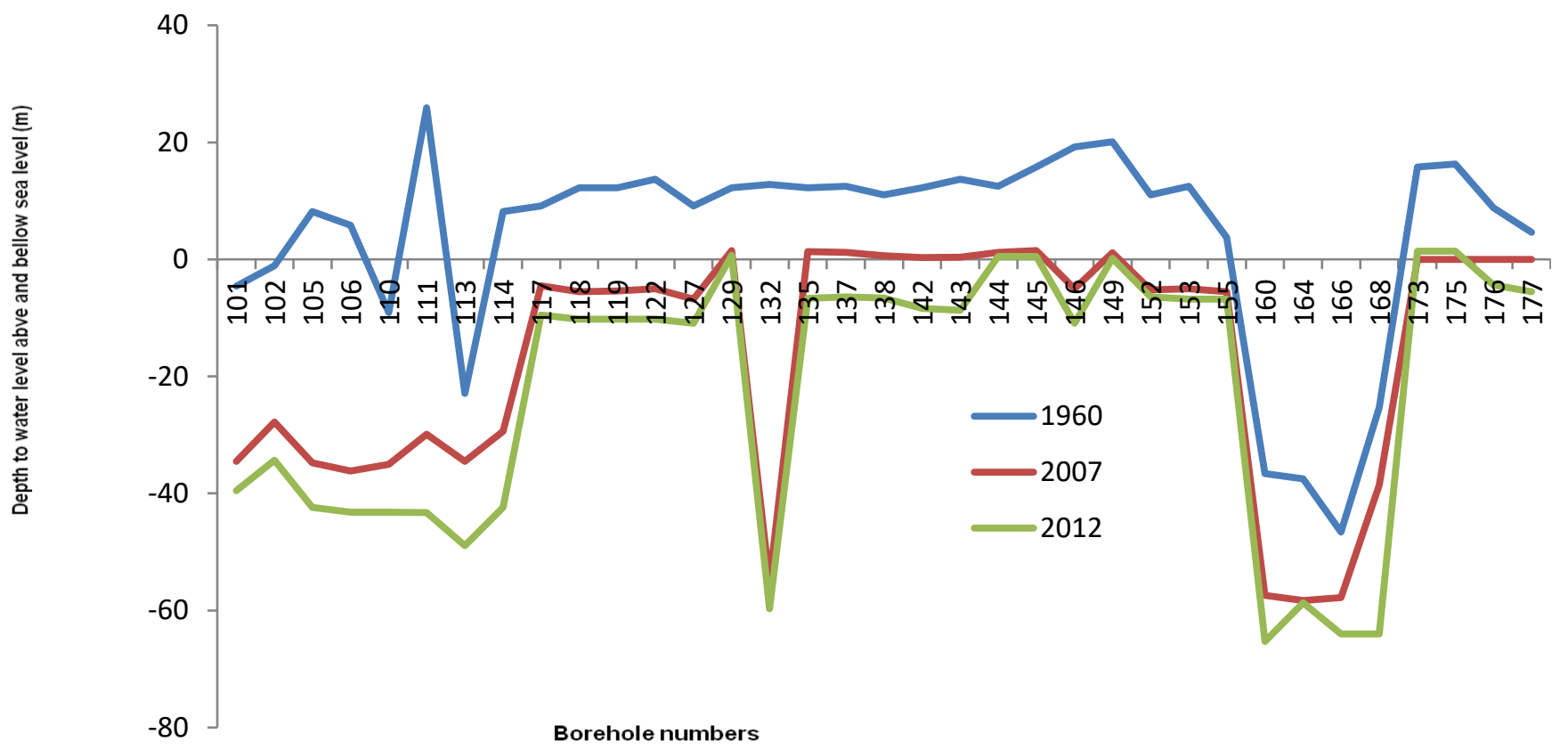

Figure 9: Plot of comparative diagram showing difference in Piezometric head in the year: 1960; 2007 and 2012. 


\section{CONCLUSION}

Groundwater in the Upper aquifer of $\mathrm{C}$ sub-zones in the Borno Basin of Nigeria is depleting from its water level without replenishment from seasonal rainfall or from river inflow due to excessive abstraction by the teaming population of the area. The present groundwater in the aquifer is Pleistocene fossil water that is being mined daily by water users either for domestic or livestock rearing.

\section{RECOMMENDATION}

There is a need for serious attention towards recharging the $C$ sub-zone as many villagers have already left their villages due to scarcity of water in their area. To supplement this problem of scarcity of water, interregional water transfer from River Benue through River Gongola and Ngadda River is an alternative solution to the problem.

\section{REFERENCES}

[1] Barber. W. M. and Jones D. R., 1960. Geology and Hydrology of Maiduguri Borno Province. Records of Geological Survey, 1958, Bulletin 34

[2] Camalt, S.W. and Tibbits, G.C., 1965. Water level and artesian pressures in the Chad Basin of Northern Nigeria. 1963-1966. Open file report U.S. Geological Survey. Pp 109

[3] Federal Survey Department Lagos 2009 Topographic Map of Nigeria on a scale of 1:500,000 Sheet 4 (fifth Edition).
[4] Avbovbo, A. A., Ayoola, E. O, and Asahon, G. A., 1986. Depositional and structural styles of the Chad Basin of North-eastern Nigeria. Bulletin of American Association of Petroleum Geologist Volume 70, No.12 pp. 22-27

[5] Kogbe, C. A., Schoeneich, K. and Ebah, E. A., 1989. Hydrogeological frame work of Maiduguri Metropolis in the Chad Basin North-Eastern Nigeria, $5^{\text {th }}$ Conference of the Nigerian Association of Hydrogeologies (NAH), Minna.

[6] Matheis, G., 1976. Short review of the geology of the Chad Basin in Nigeria. In Kogbe, C.A.(eds), Geology of Nigeria: Elizabeth and Publishing Company, Lagos. pp 288-297

[7] Offodile, M. E., 1993. Groundwater level fluctuation in the East Chad Basin of Nigeria, Journal of Mining Geology. Volume 7 No.1 and 2.pp 43-55

[8] Schoeneich, K., 1998. Geology 405 Lecture Notes. Department of Geology Ahmadu Bello University Zaria.

[9] Consulint, 1979. Hydrogeology and future exploitation of groundwater for Maiduguri water supply: Consulint Int. Service Ltd; Maiduguri. Hydrogeological Report Volume 1, pp. 186

[10] MacDonald, A. M., Cobbling and Davies, J., 2005. Developing groundwater for rural water supply in Nigeria. British Geological Survey Commission, Report CR/05/219N 